Sains Malaysiana 50(9)(2021): 2727-2741

http://doi.org/10.17576/jsm-2021-5009-19

\title{
Machining of Carbon Fibre Reinforced Polymer Composites: A Preliminary Investigation of High Power Fibre Laser
}

(Pemesinan Komposit Polimer Bertetulang Gentian Karbon: Penyelidikan Awal Laser Serat Berkuasa Tinggi)

Sharizal Ahmad Sobri*, Robert Heinemann, DaVid Whitehead, Norshah Afizi Shuaib, Mohd Faisal Abdul Hamid, Mazlan Mohamed, Wan Omar ali Saifuddin Wan Ismail, Teo Pao Ter, Mohamad Najmi Masri, MoHAmad Bashree Abu BAKar, ERWEen ABD RAHIM \& WAN AHMAD NAJMUdDIN WAN SAIDIN

\section{ABSTRACT}

Carbon fibre reinforced polymer composites (CFRP) is one of the common materials used in machining by various manufacturing industries. The most persistent challenges during the machining, both concerning the consistency of machined surfaces and the properties of the material, are the difficulties such as fibre pull-out, delamination, and decomposition of the material matrix. This preliminary research highlights the laser machining of thick CFRP using a fibre laser of more than $1 \mathrm{~kW}$. Laser machining experiments have been conducted to examine the ability of the fibre laser machine to cut thick CFRP through their high-quality laser beams. Based on the results, the study showed how the heat affected zone can be reduced when the higher cooling period is used. The effects of modulated beam mode include substantial reductions in HAZ compared with other experimental results. In all experimental attempts, substantial damage has occurred. The results are important in assessing the relationship between laser machining parameters and cutting results.

Keywords: Carbon fibre reinforced polymer composite (CFRP); heat-affected zone (HAZ); laser; machining parameters

\section{ABSTRAK}

Komposit polimer bertetulang gentian karbon (CFRP) adalah salah satu bahan popular yang digunakan oleh pelbagai industri pembuatan dalam operasi pemesinan. Kesukaran seperti penarikan serat, peleburan dan penguraian bahan matriks merupakan masalah berterusan yang sering berlaku semasa proses pemesinan dengan kedua-duanya mempengaruhi kualiti permukaan mesin dan sifat bahan. Penyelidikan awal ini menekankan pemesinan laser CFRP tebal dengan menggunakan lebih daripada $1 \mathrm{~kW}$ laser serat. Uji kaji pemesinan laser telah dilakukan untuk menilai kemampuan mesin laser serat untuk memotong CFRP tebal kerana kualiti pancaran lasernya yang unggul. Berdasarkan hasil kajian, sebuah parameter baru telah ditemukan, yang membuktikan pengurangan zon terjejas haba (HAZ) dengan ketara ketika waktu penyejukan yang lebih tinggi dikenakan. Penemuan mod balok yang dimodulasi optimis dibandingkan dengan hasil uji kaji lain dan HAZ dapat dikurangkan dengan ketara. Kerosakan besar telah berlaku dalam semua percubaan. Penemuan ini berguna dalam menggambarkan hubungan antara parameter pemesinan laser dan hasil pemotongan.

Kata kunci: Komposit polimer bertetulang gentian karbon (CFRP); laser; parameter pemesinan; zon terjejas haba (HAZ)

\section{INTRODUCTION}

Composite materials consist of two or three independent constituents or phases of manufactured or natural materials, with substantially different physical or chemical properties, which are kept separate and distinct within the finished and integrated structure. According to Abdullah et al. (2019), Erween and Sasahara (2018), Hernandez et al. (2011), Kahar et al. (2017), Lau et al. (1995), Rusli et al. 
(2017), Santhanakrishnan et al. (1988), and Shanmugam et al. (2002), composite materials are increasingly favoured in industry and are quickly gaining universal acceptance in building, furnishings, packaging, floors and panelling, and automobiles. Moreover, in many high-tech fields, such as aerospace and defence, composites are mostly used in these fields (Shanmugam et al. 2002).

Manufacturing firms around the world have no choice but to increase the quality of their manufacturing processes. Due to competitive market demands, commercial aircraft manufacturers such as Airbus and Boeing are now modifying aircraft structures to make them lighter and more powerful (Garrick 2007). In order to achieve this, according to Garrick (2007) and Mangalgiri (1999), fibre reinforced plastics, including carbon fibre reinforced plastic/polymer, are the most common and sought-after products for aircraft manufacture today. There is a significant proportion of composite materials in the latest generation of large passenger/commercial aircraft. For example, Airbus A350 and Boeing B787 have a composite content of more than 30\% and 50\% (Li \& Reza 2013).

Machining of carbon fibre reinforced polymer composites (CFRP) usually creates a heat affected zone (HAZ), due to high localization of temperatures during vaporization, and this may affect the structure of the lay-up strength (Li et al. 2008; Sheikh-Ahmad 2009). In order to find the optimum parameters in laser drilling, strategies of how to achieve fast, retaining acceptable hole quality with good repeatability have led to many variations in laser drilling strategies by industry players (Steen \& Mazumder 2010). It was found experimentally by previous researchers that laser power and cutting speed are the most significant parameters affecting surface roughness (Kumar 2018; Lau et al. 1995; Mathew et al. 1999; Reza \& Li 2013; Singh \& Maurya 2017). In addition, for kerf width, the laser power, cutting speed, gas pressure, and duty cycle are the most significant parameters, while taper angle has the same factors as kerf width but with additional concern for pulse frequency. For the HAZ, the most significant parameters are laser power, cutting speed, gas pressure, pulse repetition rate, and pulse duration.

Other parameters such as multi-pass cutting and focal plane locations, which are still scarce in the literature, may still require more study in order to achieve the best results possible with laser machining. Additionally, no attempts were successful in penetrating a complete hole with a CFRP panel thicker than $5 \mathrm{~mm}$. Using a fibre laser machine and gas-assisted scanning head, it is expected that it will be possible to drill approximately one-inch thick carbon fibre sheet due to successfully drilling of 50 $\mathrm{mm}$ thick steel with a $700 \mathrm{~W}$ fibre laser machine (Goeke \& Emmelmann 2010).

This article presents the preliminary experimental process of laser machining of thick CFRP composite composites (samples provided by AIRBUS UK) by using a $16 \mathrm{~kW}$ fibre laser machining centre. The results were helpful in explaining the relationship between cutting efficiency and the machining parameters of laser machining and cutting.

\section{Materials AND Methods}

Multi-directional and multi-layer carbon fibre composites, with a total thickness of $25.4 \mathrm{~mm}$ (1 inch), are used for the experiments. It was provided in 400 $(\mathrm{L}) \times 400(\mathrm{~W}) \times 25.4(\mathrm{~T}) \mathrm{mm}$ flat panels and was divided into $50 \times 20 \mathrm{~mm}$ blocks. Digital microscope (Keyence VHX-500X) located at Laser Processing Research Centre (LPRC), The University of Manchester was used to assess the defects. Airbus UK did not disclose any details about it, which the authors were required to conduct limited examinations to determine the specifications. A visual inspection showed that the lamina was stacked at $0 \% / 90^{\circ} /-45^{\circ} / 90^{\circ} / 90^{\circ} /-45^{\circ} / 90^{\circ} /-45^{\circ} / 90^{\circ} / 90^{\circ} /-45^{\circ} / 90^{\circ} / 90^{\circ} /-$ $45^{\circ} / 90^{\circ} / 90^{\circ} / 0^{\circ}$ and the thickness of each ply was 0.22 $\mathrm{mm}$. An additional thickness of $0.14 \mathrm{~mm}$ (i.e. a protection layer) located at the first layer of CFRP. Table 1 shows the properties of CFRP material.

TABLE 1. Properties of CFRP sample

\begin{tabular}{llll}
\hline Material & Grade & Yield strength & Density \\
\hline CFRP & M21 & $835 \mathrm{MPa}$ & $2.06 \mathrm{~g} / \mathrm{cm}^{3}$ \\
\hline
\end{tabular}


The machining of thick CFRP was conducted using an IPG/Kuka $16 \mathrm{~kW}$ fibre laser with a robotic remote cutting system located at The Dalton Nuclear Institute, The University of Manchester. The machine system features a wide range of fibre diameters and the option to terminate to up to 6 ports from one power source. The system is also attached to 3 robot arm facilities called the KUKA manufacturer which can be used for cutting, welding, and deposition.

The six experiments were conducted at the $16 \mathrm{~kW}$ fibre laser machining centre. The $16 \mathrm{~kW}$ fibre laser machine only permitted laser power more than $500 \mathrm{~W}$ at intervals of $100 \mathrm{~W}$, while laser power below $500 \mathrm{~W}$ was not applicable. This was the case because the energy needed to melt or vaporise the fibre was higher than the energy required to melt or vaporise the polymeric matrix. This was crucial for the machining of $25.4 \mathrm{~mm}$ thick composite and only at a lower wattage (i.e. below $500 \mathrm{~W}$ ) did the laser beam become unusable.

Table 2 provides the fixed parameters applied to all experiments. An additional parameter was included in the experiments - the cooling time between passes. Figure 1 shows the positions where the laser beam would stop for a few seconds at one point (i.e. red dot) after a single pass, then move to the other point (i.e. blue dot) and stop again for the same time. The laser beam repeated this movement until it reached a maximum number of multi-passes, which was set in each different experimental condition. The main reason for adding this parameter was to avoid heat accumulation and to optimise the laser energy. Experimental conditions are described in the next paragraphs including the new parameter, cooling time between passes, by manipulating the interaction time between the laser beam and workpiece material. Furthermore, these experiments were begun with the subject of trench cutting since this is where the fundamentals of laser interaction with material were first partially explored (Abrate \& Walton 1992; Cenna \& Mathew 1997; Li et al. 2008; Mathew et al. 1999; Reza \& Li 2013; Sheikh-Ahmad 2009; Sobri et al. 2018a). The second plausible cause for the protection of the lens is to prevent the risk of lens damage due to dust.

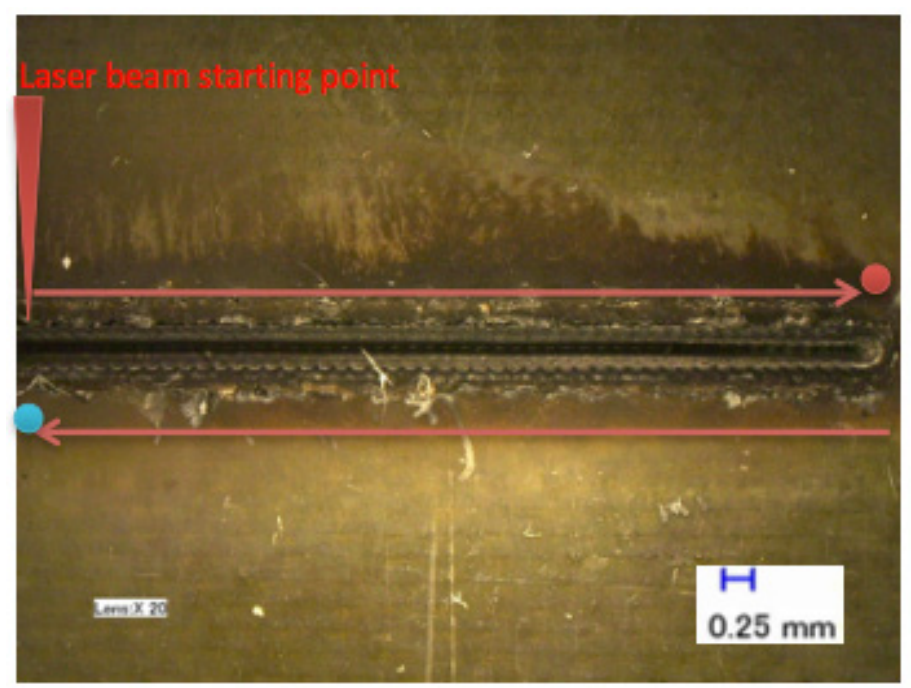

FIGURE 1. Linear movements of laser beam, and cooling time points from top view of workpiece material 
TABLE 2. Fixed parameters for all experiments

\begin{tabular}{ll}
\hline Gas type & Argon \\
\hline Gas pressure & 8 bar \\
Gas flow rate & 40 litre $/ \mathrm{min}$ \\
Nozzle size & Diameter of $1 \mathrm{~mm}$ \\
Stand-off distance & $1 \mathrm{~mm}$ \\
\hline
\end{tabular}

The first experimental work was conducted to identify any effect on depth of hole as well as thermal damage when setting the laser power to more than $1 \mathrm{~kW}$. In
Table 3, all parameters were conducted in constant values except for the laser power as a variable parameter. The main concern for this experiment was to study the potential of laser machining by using high power.

TABLE 3. Process parameters for Experiment 1

\begin{tabular}{ll}
\hline Laser power & $500 \mathrm{~W}, 1 \mathrm{~kW}, 1.5 \mathrm{~kW}$ \\
\hline Scanning speed & $10 \mathrm{~mm} / \mathrm{s}$ \\
Pulse ratio & Continuous wave $(\mathrm{CW})$ mode \\
Cutting pass setting & 5 times \\
\hline
\end{tabular}

The second experiment was carried out to study the influence of pulse ratio in cutting thick CFRP. Table 4 shows the process parameters involved in second experiment. The first attempt, i.e. Combination 1 and 2, was studied by identifying any effect of pulse ratio by setting at higher pulse-off time on HAZ or other potential damages. This was a first time to set at high pulse-on time as well as pulse-off. The second attempt (i.e. Combination 3 and 4) was conducted by setting an equal value for the pulse ratio. The changes were made on the pulse ratio (i.e.
50:50 and 50:150), and multiple passes (i.e. 20 passes) This is because to study the potential of interaction time between the pulsed laser mode and workpiece. Moreover, these parameter values were selected based on the common range in previous research attempts as highlighted in the Introduction section except for pulse off-time, which it was the first attempt to conduct beyond $90 \mathrm{~ms}$. For multiple passes, the same reason was based on the work of Sobri et al. (2018b) regarding the recommendation on the number of passes. 
TABLE 4. Process parameters for Experiment 2

\begin{tabular}{ll}
\hline Combination 1 & $1 \mathrm{~kW}$ \\
Laser power & $10 \mathrm{~mm} / \mathrm{s}$ \\
Scanning speed & $10 \mathrm{~ms}$ 'on': $90 \mathrm{~ms}$ 'off' \\
Pulse ratio & 1 pass \\
Cutting pass setting & $1 \mathrm{~kW}$ \\
\hline Combination 2 & $10 \mathrm{~mm} / \mathrm{s}$ \\
Laser power & $50 \mathrm{~ms}$ 'on': $150 \mathrm{~ms}$ 'off' \\
Scanning speed & $1 \mathrm{pass}$ \\
Pulse ratio & \\
Cutting pass setting & $500 \mathrm{~W}$ \\
\hline Combination 3 & $10 \mathrm{~mm} / \mathrm{s}$ \\
Laser power & $10 \mathrm{~ms}$ 'on': $10 \mathrm{~ms}$ 'off' \\
Scanning speed & $20 \mathrm{passes}$ \\
Pulse ratio & \\
Cutting pass setting & $500 \mathrm{~W}$ \\
\hline Combination 4 & $10 \mathrm{~mm} / \mathrm{s}$ \\
Laser power & $50 \mathrm{~ms}$ 'on': $50 \mathrm{~ms}$ 'off' \\
Scanning speed & $20 \mathrm{passes}$ \\
\hline Pulse ratio & \\
Cutting pass setting &
\end{tabular}

Table 5 provides the process parameters for experiment 3 . The pulse rate ratios used were based on the work of Sobri et al. (2018b) and it has also applied to the $16 \mathrm{~kW}$ fibre laser machine for the machining of CFRP, in order to validate the fact that the pulse offtime influences the depth of the trench cut and the HAZ where this was the first attempt to observe the trench cut depth. However, in experiment 3, a cooling time between passes was added due to the intention of optimising the laser energy to allow energy (heat) to be deposited into the material to disperse it, thus, reducing the amount of HAZ. The fourth experiment was focused on the variation of scanning speeds in order to identify any effects of the interaction time on cut depth and thermal damage. Information about the process parameters is listed in Table 6.

TABLE 5. Process parameters for Experiment 3

\begin{tabular}{ll}
\hline Laser power & $500 \mathrm{~W}, 1 \mathrm{~kW}$ \\
\hline Scanning speed & $10 \mathrm{~mm} / \mathrm{s}$ \\
Pulse duration & $10 \mathrm{~ms}$ \\
Pulse-off time & $10 \mathrm{~ms}, 50 \mathrm{~ms}$ \\
Cooling time between passes & $1 \mathrm{~s}, 2 \mathrm{~s}, 5 \mathrm{~s}, 10 \mathrm{~s}$ \\
Cutting pass setting & 20 passes \\
\hline
\end{tabular}


TABLE 6. Process parameters for Experiment 4

\begin{tabular}{ll}
\hline Laser power & $500 \mathrm{~W}, 1 \mathrm{~kW}$ \\
\hline Scanning speed & $2 \mathrm{~mm} / \mathrm{s}, 5 \mathrm{~mm} / \mathrm{s}, 10 \mathrm{~mm} / \mathrm{s}$ \\
Pulse duration & $10 \mathrm{~ms}$ \\
Pulse-off time & $50 \mathrm{~ms}, 90 \mathrm{~ms}$ \\
Cooling time between passes & $1 \mathrm{~s}, 5 \mathrm{~s}$ \\
Cutting pass setting & 20 passes \\
\hline
\end{tabular}

\section{RESULTS AND DISCUSSION}

In Figure 2, the effect of laser power on trench depth is shown by the blue line and the effect of the HAZ is the red one. Figure 3 shows the effect of laser power at 1.5 $\mathrm{kW}$ and an $8 \mathrm{~mm}$ layer of carbon fibre-reinforced polymer split away from the main structure due to the high heat. The results showed that, as anticipated, laser power increased with trench cut depth, while, laser power also increased as the trench cut depth increased. The highest trench cut depth was $7 \mathrm{~mm}$ at the laser power of $1.5 \mathrm{~kW}$. Higher power does affect the trench cut depth as more energy transfer from the cutting zone to borehole wall is occurred, which led to higher material removal can be achieved. However, the major problem is the size of HAZ significantly increased due to the increase in the beam energy absorbed by the material as clearly be seen in Figure 2, which it is also a linearly-related between power and HAZ. Since carbon fibres took more heat transfer to cut due the characteristic of a higher thermal conductivity compared to the matrix, the difference between the vaporization temperatures of the fibres and that of the matrix became larger and caused the material to burn and a few layers get separated from the workpiece block as can be seen in Figure 3(b).

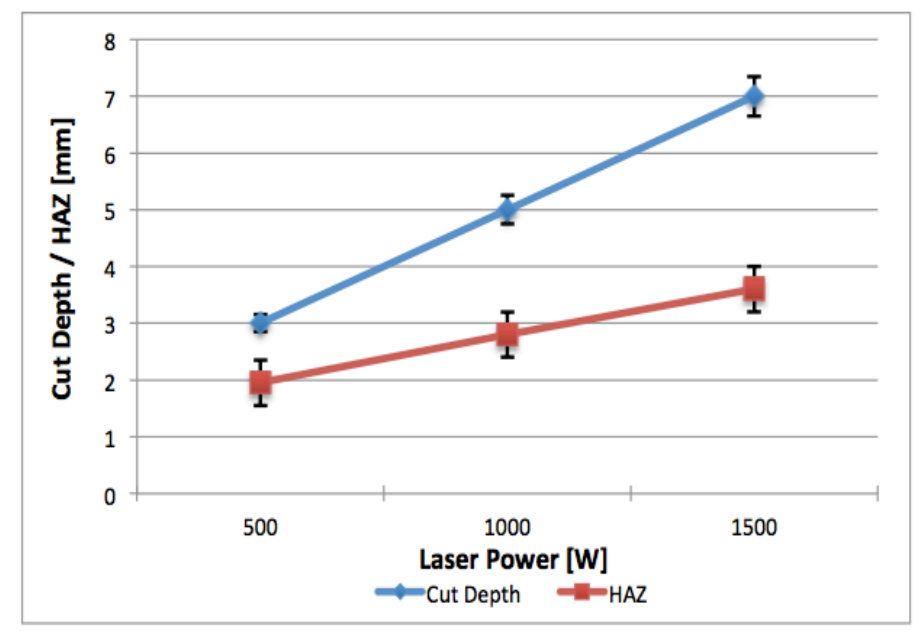

FIGURE 2. The effect of high laser power on trench cut depth and HAZ 


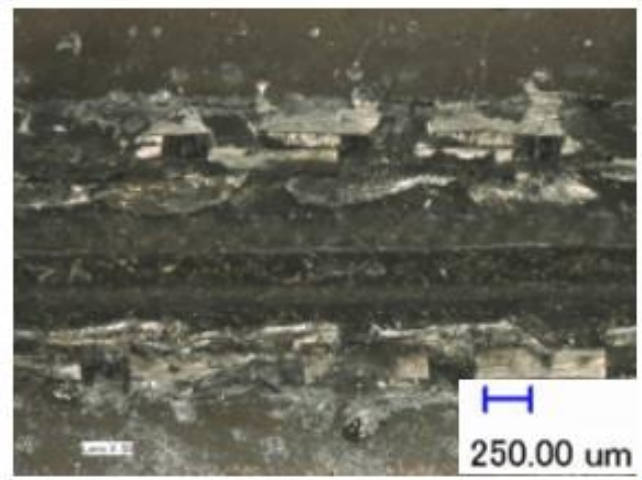

(a)

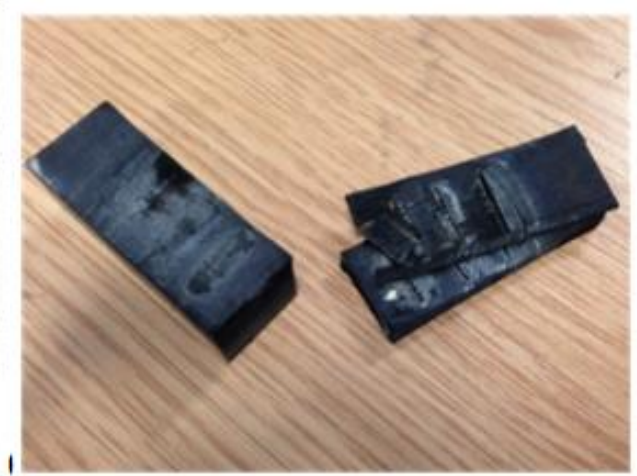

(b)

FIGURE 3. Result of laser interaction at $1.5 \mathrm{~kW}$ laser power: (a) top view of middle trench; (b) $8 \mathrm{~mm}$ thick layer detached

Moreover, as can be seen in Figure 3(b), there were depth marks left on the left sample bit when an $8 \mathrm{~mm}$ thick layer was detached. Apparently, the laser beam caused these marks and it was able to reach to more than $7 \mathrm{~mm}$ depth. This could due to thermal stresses, which occurred during laser cutting caused by high thermal gradients adjacent to the cutting zone and the particular structure of the layer. Furthermore, it is possible that the differences in the thermal expansion coefficients of the constituents were significantly larger, particularly, the thermal stresses that extended inside the composite laminate. Trench cut at laser power $1.5 \mathrm{~kW}$ was repeated twice and two samples showed similar effect as before; a $6 \mathrm{~mm}$ thick layer was detached in the second attempt then in third attempt, $7 \mathrm{~mm}$ thick layer was detached as well. Thus, the laser power of $1.5 \mathrm{~kW}$ was discarded in the subsequent experimental works because the material was prone to severe damages.

Figure 4 shows the overall HAZ for the four combinations. The effect of the pulse ratio on HAZ is shown in Figure 5. The upper diagrams 5(a) \& 5(b) shows the results of combination 1 and 2 while the bottom diagrams 5(c) \& 5(d) provide the results of combination 3 and 4. All samples were repeated three times and measurement of HAZ was calculated only at the top view of trench cut in average values.

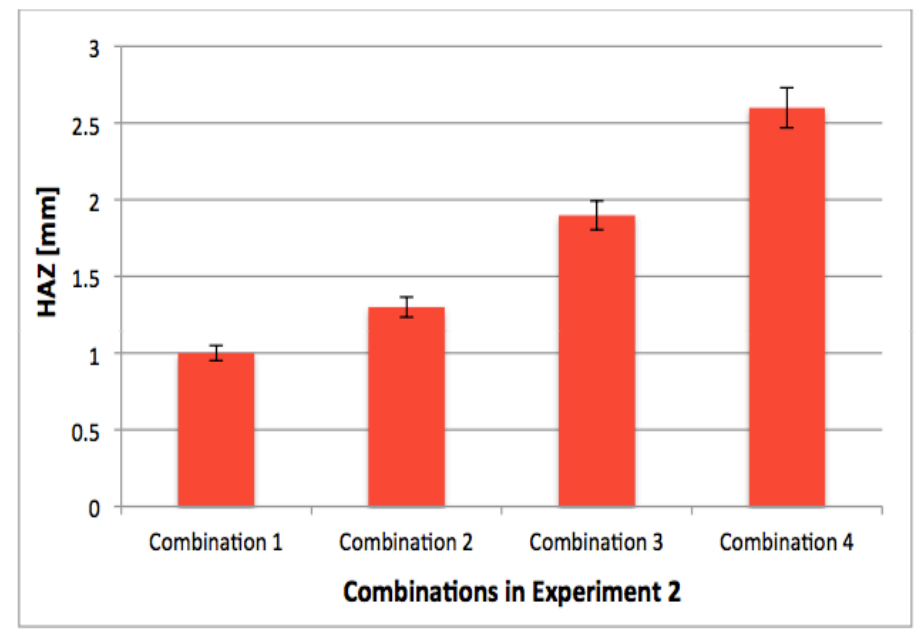

FIGURE 4. The effect of pulse ratio on HAZ 


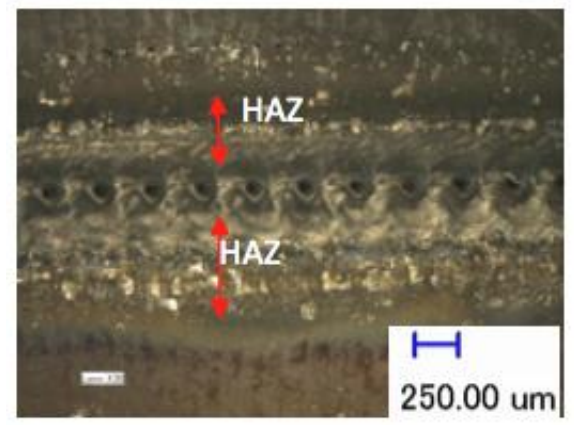

(a)

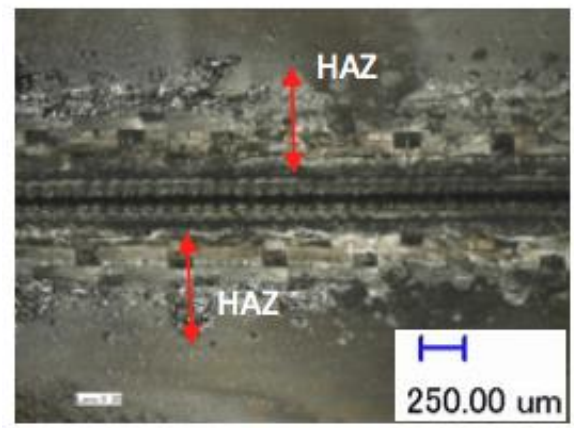

(c)

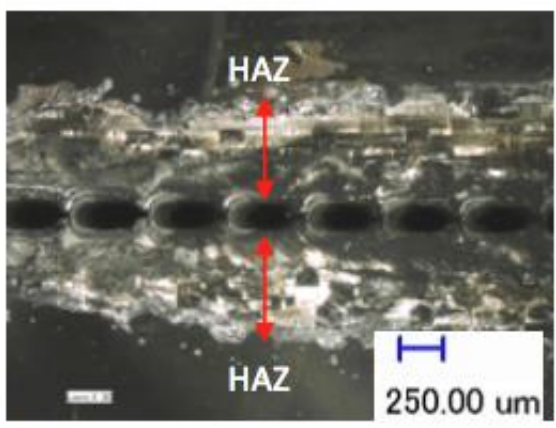

(b)

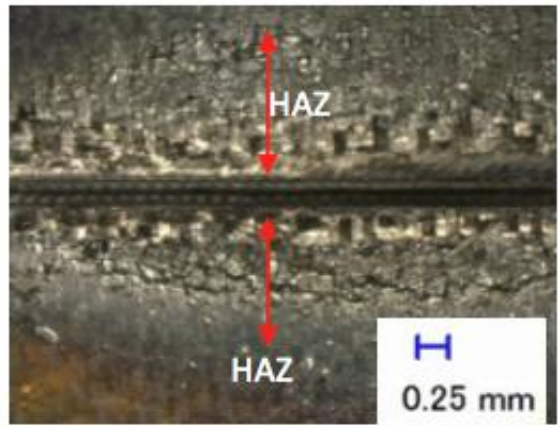

(d)

FIGURE 5. The influence of pulse ratio in experiment 2: (a) combination

1 ; (b) combination 2; (c) combination 3; and (d) combination 4

Based on the observations in Figures 4 and 5, it is apparent that the level of HAZ was significantly higher at combinations 3 and 4 . This indicated that higher pulse-on time and multiple passes strongly affected the vaporisation mechanism in the material. Consequently, more energy was absorbed into material and caused more heat transfer, which created a wider HAZ. In the meantime, combinations 1 and 2 on HAZ are considerably accepted which it had achieved less than $2 \mathrm{~mm}$. This is because it did not involve a major post-processing work and preference that should be achieved less than $2 \mathrm{~mm}$ for HAZ as desired by the aerospace industry ( $\mathrm{Li}$ et al. 2008; Reza \& Li 2013; Sandvik 2019). It was noted that the pulse-off time of 90 and $150 \mathrm{~ms}$ created significant series of spots or dimples. The intermittent shot by the laser beam caused these dimples due to the very short interaction time between laser power and workpiece.

Meanwhile, in combination 1, the gap between shots was wider than the gap that occurred in combination 2 .
This might be caused by the pulse-on time of $50 \mathrm{~ms}$, which created a large beam shot. In this regard, the $50 \mathrm{~ms}$ pulse-on time had more interaction time to vaporise the material compared to the $10 \mathrm{~ms}$ pulse-on time because of limited laser energy and produced smaller spots. The pulse on-off ratios of $10 \mathrm{~ms}: 10 \mathrm{~ms}$ and $10 \mathrm{~ms}: 90 \mathrm{~ms}$ were found to be better than $50 \mathrm{~ms}: 50 \mathrm{~ms}$ and $50 \mathrm{~ms}: 150 \mathrm{~ms}$ for the HAZ. It can be postulated that if combination 2 and 4 were conducted in multiple passes, with more than 20 passes, the HAZ length for this combination would be significantly larger than the other combinations. Thus, subsequent experiments were focused on laser power levels at $1 \mathrm{~kW}$ and $500 \mathrm{~W}$, and pulse on-off ratio settings of $10 \mathrm{~ms}: 10 \mathrm{~ms}, 10 \mathrm{~ms}: 50 \mathrm{~ms}$ and $10 \mathrm{~ms}: 90 \mathrm{~ms}$.

Figure 6 shows the comparison between different cooling time of passes with laser power and pulse ratio variations; Figure 6(a) shows the results on HAZ while Figure 6(b) provides the results on trench cut depth. Each graph shows a four-colour indicator at the 
right side, and each colour illustrates different cooling time between passes. Meanwhile, Figure 7 shows the comparison between two cooling time; Figure 7(a) the left side illustrates 1-second cooling time and Figure 7(b) the right side shows 2-second cooling time. Based on the results in Figure 6, a significant reduction on the trench cut depth can be observed as well as HAZ when increasing the cooling time at all laser power-pulse ratio combinations except the cooling time for 1 and 2 seconds. This showed similar results with the highest values on the cut depth and HAZ. Moreover, as expected, the highest values for the trench cut depth and HAZ, were 4.7 and 2.3 $\mathrm{mm}$, respectively. These values were produced by laser power-pulse ratio of $1 \mathrm{~kW}-10 \mathrm{~ms}: 10 \mathrm{~ms}$ combination due to short pulse-off time.

Figures 6 and 7 show that in every single pass, there was no noticeable difference between the one and two-second cooling time. The results for trench cut depth and HAZ were similar, with no extreme alteration of the material. Consequently, when the laser beam was off, there were no more energy being deposited into the material and the laser beam continued for the next pass after the cooling time ended. The possible reason for this is the amount of energy disappearance had not significantly affected the material, even though the cooling time changed from 1 to 2 seconds. As a result, changes were made to the cooling time in order to observe any significant alteration in the cut depth and quality appearance. This was done through comparing three cooling times (2, 5 and 10 seconds). Figure 8 shows the typical examples for 2-, 5- and 10-second cooling times. Furthermore, Figure 8(a), 8(b), and 8(c) shows the image results of 2, 5, and 10 seconds at top view and crosssection view, respectively, which influence the trench cut depth and HAZ. The measurement of trench cut depth was done by randomly selecting the depth at three different locations (i.e. the beam starting point, the middle of the trench and the final beam point) then all measured values were calculated in average. This was also applied to the other experiments.

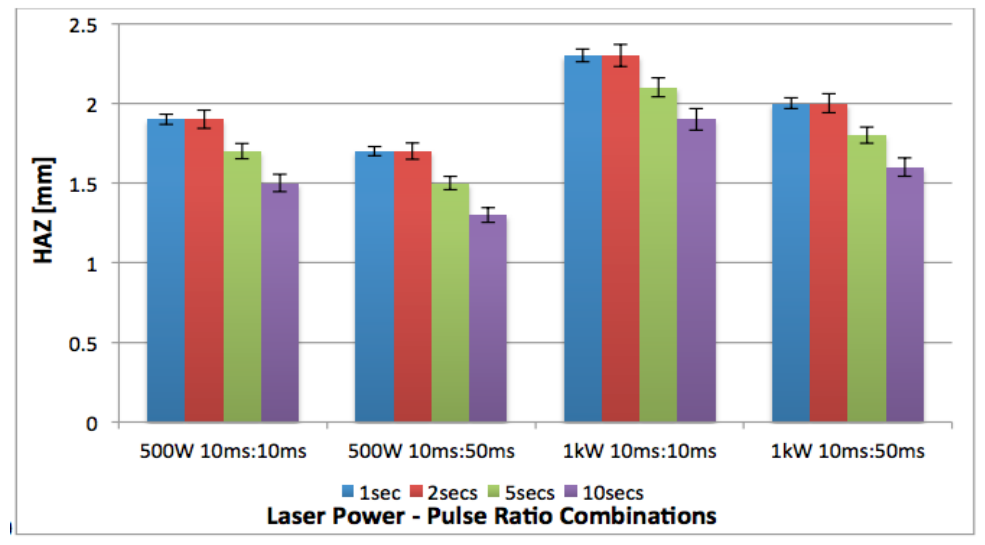

(a)

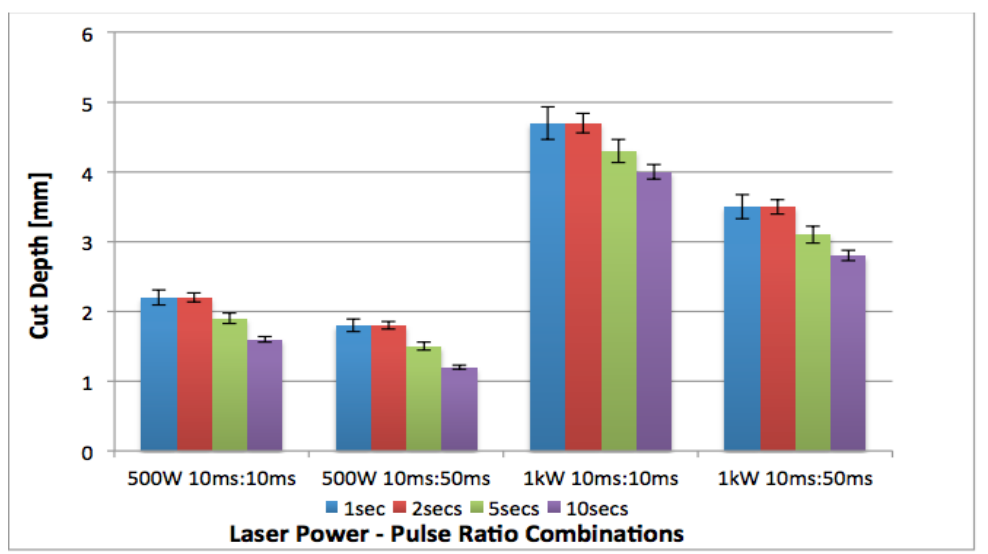

(b)

FIGURE 6. The effect of cooling time between passes on: (a) HAZ; and

(b) trench cut depth 


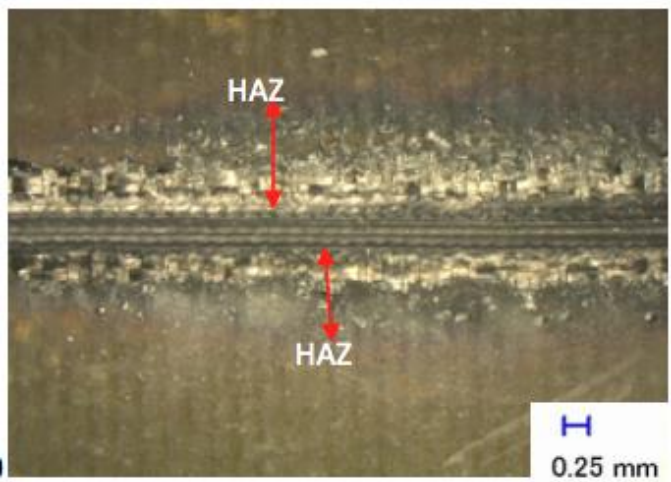

(a)

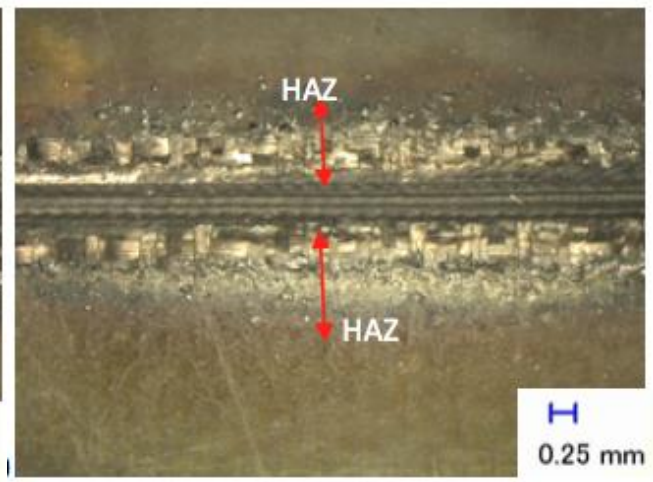

(b)

FIGURE 7. Influence of cooling time on trench cut depth and HAZ at laser power of $1 \mathrm{~kW}$ and pulse ratio of $10 \mathrm{~ms}: 10 \mathrm{~ms}$ : (a) 1 second; and (b) 2 seconds

The area of HAZ became smaller when the heat propagated perpendicularly to the fibre direction. In addition to the effects on the HAZ, it is believed that delamination occurred between two or more lamina, and which was clearly shown adjacent to the work path of the laser beam. A few voids between fibres were also noticed in different orientations, this was caused by the effects of partial polymer decomposition during the machining process. Meanwhile, a different outcome could be observed in the cross-section view as shown in Figure 8 . This is where the heat was spread vertically downward or concentrated towards the bottom when the cooling time increased which is against the common flow path observed in other samples, where the heat usually spread along the fibres horizontally. This indicated that the amount of energy depends on the power and the duration of 'on' and not the cooling/dwell time. At this point, the cooling might allow the energy to dissipate into the material, preferably along the fibres. It allowed the heat to spread out, especially along the fibres, thereby, distributing the heat more evenly and resulting in a cooler centre. Accordingly, the cooling period could be sufficient for the heat to diffuse through the fibres before the next pass, as it allowed the laser beam to cut a more cooled down workpiece material and this could influence the cutting depth. However, a larger cutting depth depends on the output power and in order to simultaneously minimise the HAZ and produce a full cut, the minimum amount of heat required should be used.

Meanwhile, the experimental results of the 10-second cooling time showed that the highest trench cut depth achieved was $4 \mathrm{~mm}$ at the laser power-pulse ratio of 1 $\mathrm{kW}-10 \mathrm{~ms}: 10 \mathrm{~ms}$ combination, which was lesser than for the 5 -second cooling time. This is because the laser beam had already been switched off for longer (i.e. there was no energy pumped into the material during the cooling time) but substantial amount of energy is still required to cut deeper. Conversely, the HAZ for the 10-second cooling time was better than HAZ for 2- or 5-second cooling time. However, a longer cooling time will affect the production rate, making it unfavourable for industrial use. Thus, in the subsequent experiments, the 10-second cooling time was discarded, and the work continued with the 2 and 5 -second cooling times.

Figure 9 shows the effect of scanning speed with various laser power-pulse ratio-cooling time combinations on trench cut depth and HAZ; Figure 9(a) shows the effect of scanning speed on the trench cut depth while Figure 9(b) provides the effect of scanning speed on HAZ. The three colour indicators located on 

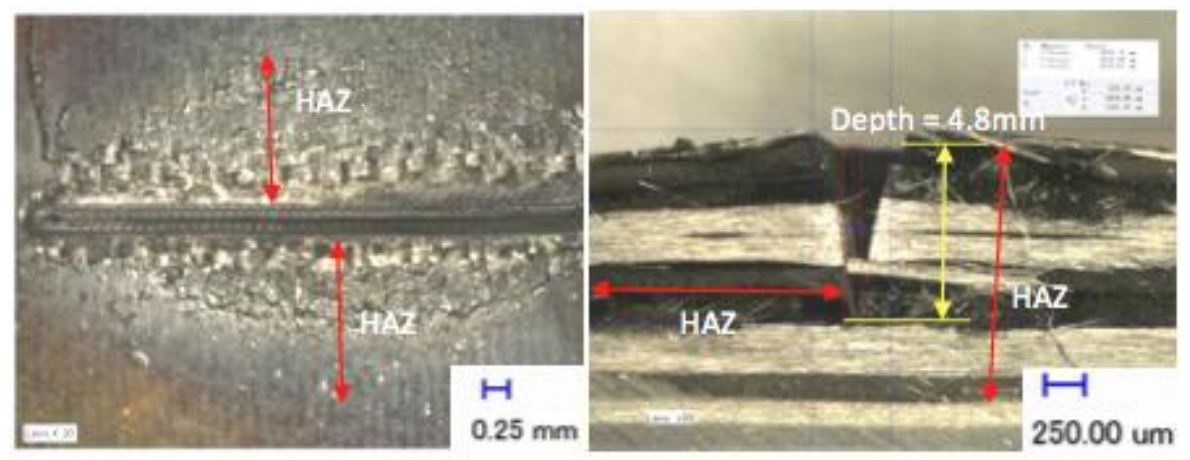

(a)
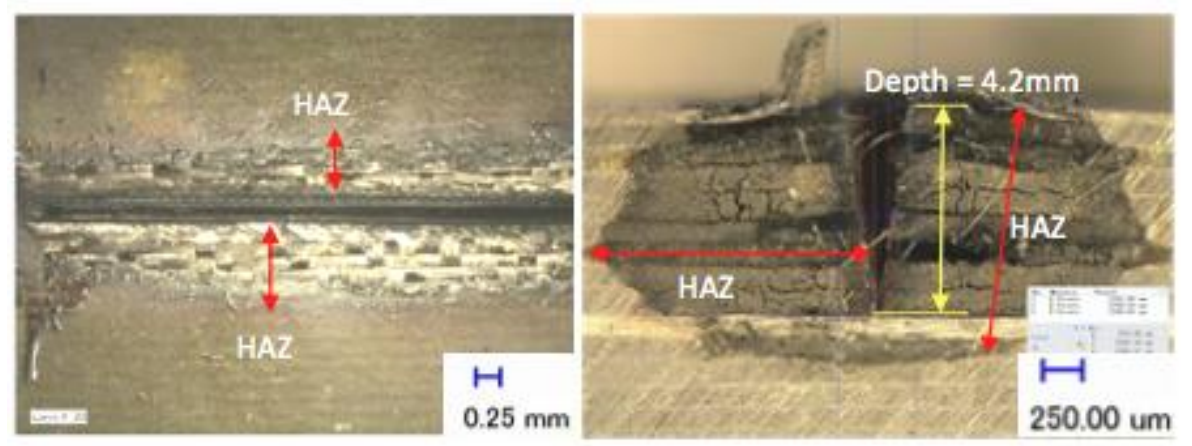

(b)
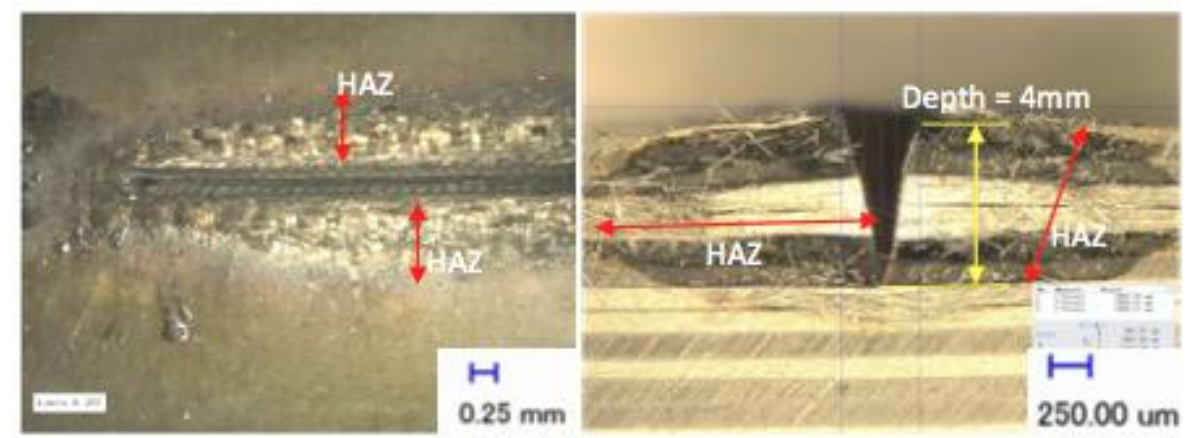

FIGURE 8. Typical examples of cooling time between passes at laser power-pulse ratio combination of $1 \mathrm{~kW}-10 \mathrm{~ms}: 10 \mathrm{~ms}$ : (a) 2 seconds; (b) 5 seconds; and (c) 10 seconds

the right side of Figure 9(a) indicate three different scanning speeds, which were also applied in Figure 9(b). Meanwhile, Figure 10 shows a typical example of a workpiece cut by $16 \mathrm{~kW}$ fibre laser; Figure 10(a) illustrates the workpiece, the top view on the left and the cross-section view on the right, at the scanning speed of $2 \mathrm{~mm} / \mathrm{s}$ with laser power-pulse ratio-cooling time of 1 kW-10 ms:90 ms-1 sec combination; Figure 10(b) shows the workpiece result at the scanning speed of $5 \mathrm{~mm} / \mathrm{s}$ with $1 \mathrm{~kW}-10 \mathrm{~ms}: 50 \mathrm{~ms}-1 \mathrm{sec}$ combination. 
Based on the results, the trench cut depth was significantly reduced when the scanning speed increased. The deepest trench cut achieved was $3.8 \mathrm{~mm}$ at the scanning speed of $2 \mathrm{~mm} / \mathrm{s}$ with $1 \mathrm{~kW}-10 \mathrm{~ms}: 50 \mathrm{~ms}-1 \mathrm{sec}$ combination. This can be confirmed due to the scanning speed controls of the interaction time. Even though the laser beam action was limited due to the pulse ratio setting, the laser beam at the scanning speed of $2 \mathrm{~mm} / \mathrm{s}$ still managed to cut slightly deeper compared to the other two speeds. Consequently, the slower the scanning speed, the longer the interaction time, more energy was absorbed and as much as possible conduction could be produced into the workpiece. In the meantime, laser power also influenced the cut depth, as can be seen in Figure 9 by comparing between $500 \mathrm{~W}$ and $1 \mathrm{~kW}$ at any combination and scanning speed. Higher power leads to higher removal material, as high temperature is required for cutting the fibres.

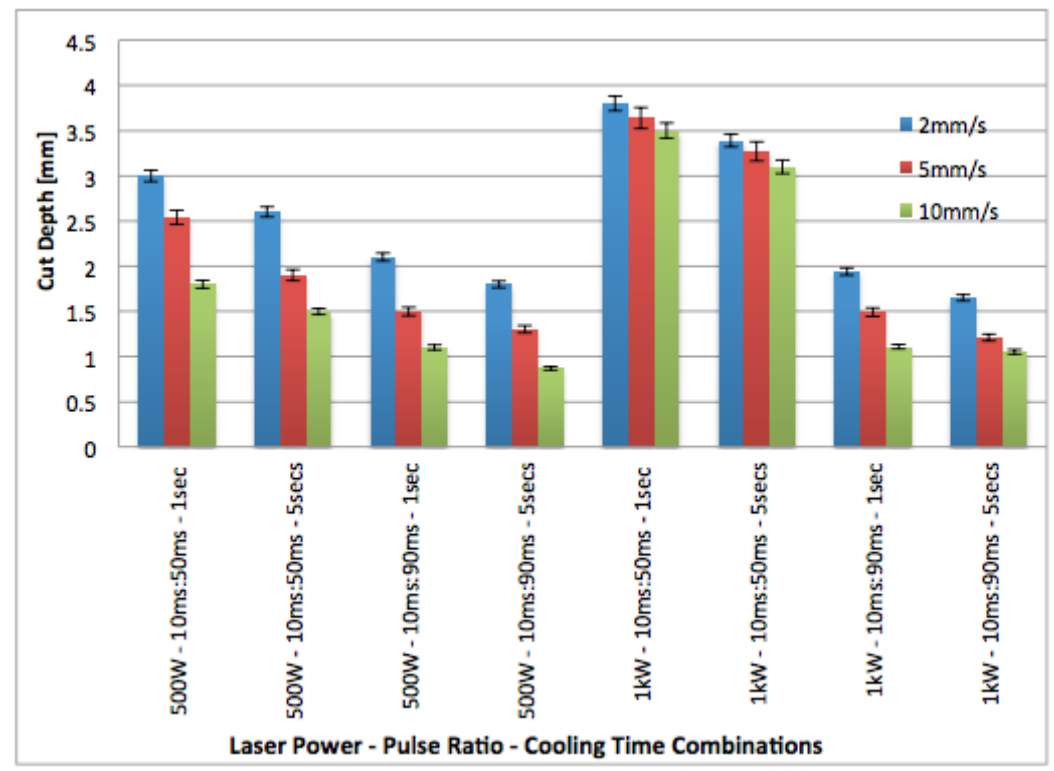

(a)

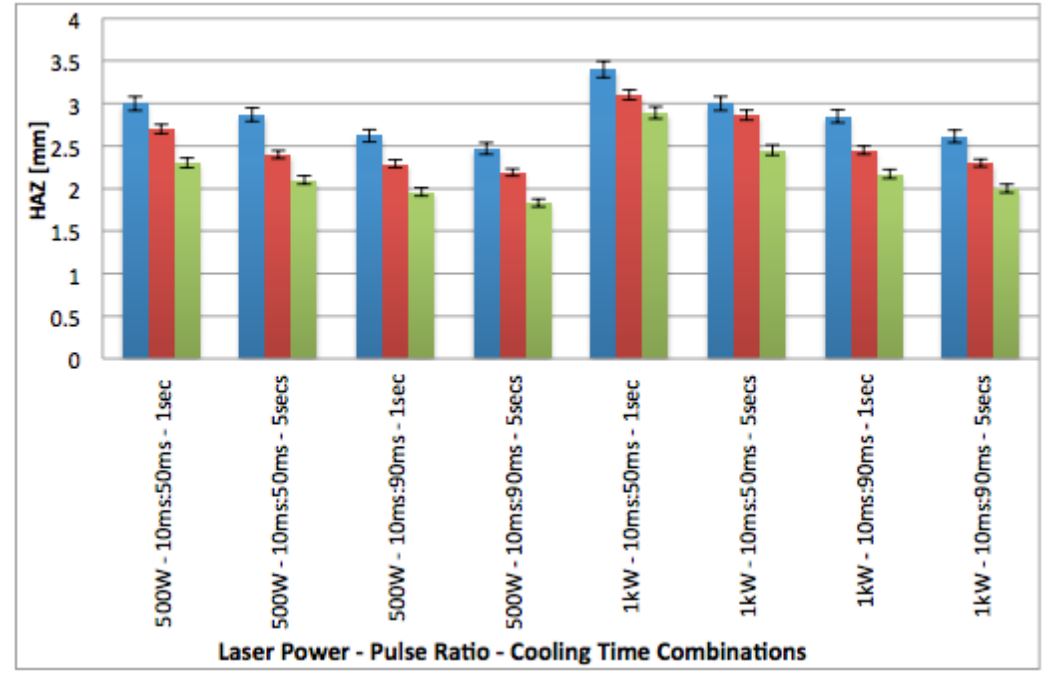

(b)

FIGURE 9. The effect of scanning speed with various combinations on the workpiece: (a) cut depth; and (b) HAZ 

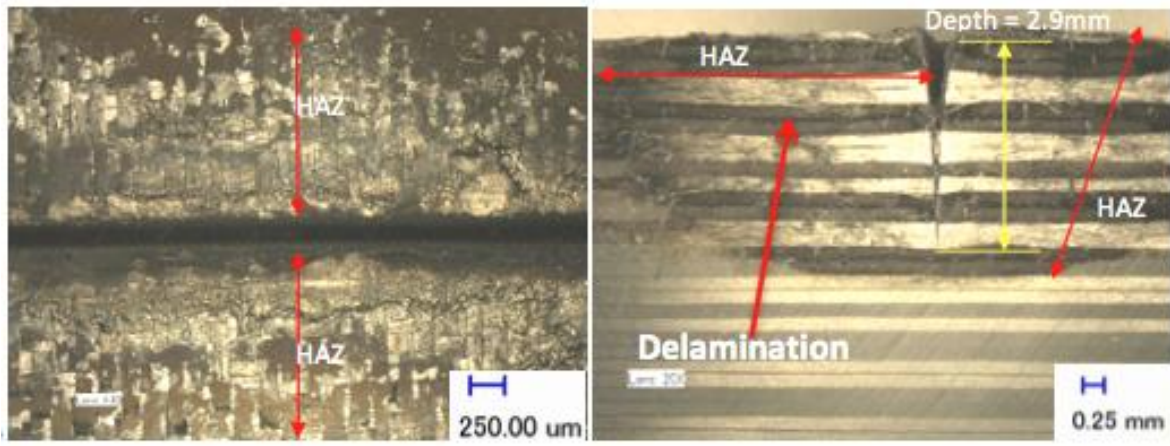

(a)
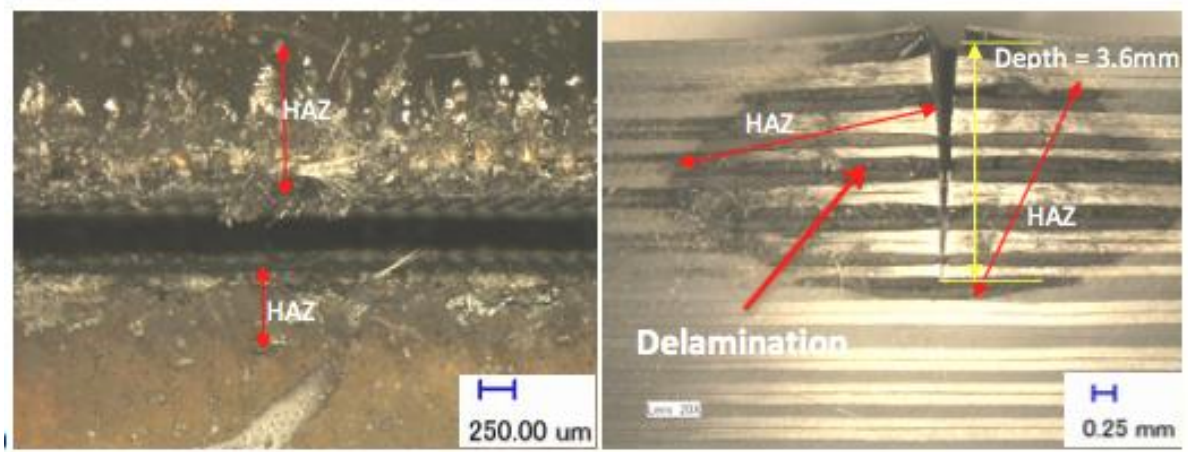

(b)

FIGURE 10. Influence of scanning speed with laser power-pulse ratio-cooling time combination on the cut depth and HAZ: (a) scanning speed of $2 \mathrm{~mm} / \mathrm{s}$ with $1 \mathrm{~kW}-10 \mathrm{~ms}: 90 \mathrm{~ms}-1 \mathrm{sec}$ combination; and (b) scanning speed of $5 \mathrm{~mm} / \mathrm{s}$ with 1 kW-10 ms:50 ms-1 sec combination

Scanning speed is an influential factor that significantly reducing the defects such as HAZ, matrix recession and others, and this can be confirmed by observing the results in Figure 9. It is apparent that with a low scanning speed of $2 \mathrm{~mm} / \mathrm{sec}$, the HAZ and other thermal damage were significant, and this indicated that the damage had increased when the scanning speed was slower due to the longer interaction time between the laser beam and material. It can be clearly seen that the cut quality for a $50 \mathrm{~ms}$ pulse-off time was better than for the short pulse-off time (i.e. $10 \mathrm{~ms}$ ) based on the experiment 3.3 results. Furthermore, the reduction of HAZ is evident in Figure 10, and there was no severe matrix recession occurred, either at the top surface or in the cross-section. In addition, a few delamination defects are seen in Figure 10 and as the laser beam moves, it produced a continuous cut path, as shown in Figure 10, which is similar to what observed in the continuous wave (CW) mode. However, there is a potential threat towards the laser scanning head where the slow scanning can be detrimental to the laser lens system, since the lens can be damaged by excessive exposure to evaporated materials. It was proven that when the scanning speed was set at $2 \mathrm{~mm} / \mathrm{s}$ with $500 \mathrm{~W}$ laser power, the $50 \mathrm{~ms}$ pulse off-time and the 1-second cooling 
time showed severe damages, such as resin recession as well as HAZ. Moreover, the damages were escalated when the machine was set at $1 \mathrm{~kW}$ laser power with cutting speed of $2 \mathrm{~mm} / \mathrm{s}, 50 \mathrm{~ms}$ pulse off-time and 1-second cooling time. By understanding the fundamentals based on these results, it was confirmed that scanning speed is the most affecting parameter on HAZ and other damages.

\section{CONCLUSION}

The aim of this research was to assess the feasibility of machining thick CFRP composites by using $16 \mathrm{~kW}$ fibre laser in order to determine the influence of machining input variables on key output measures. On the basis of research work in this stage on $16 \mathrm{~kW}$ fibre laser, by introducing a new parameter such as cooling time between passes, it provides a considerable reduction of HAZ when higher cooling time is imposed. This may be a potential in cutting CFRP composites whereby a shorter period can be used for cutting and a long time for cooling can be introduced. It is possible to use a modulated laser pulse in deep hole drilling. A positive result was achieved in modulated beam mode which demonstrated a significant improvement compared to other experimental results, where HAZ could be significantly reduced. With high beam strength and more concentrated beam modulation, the heating in the process of drilling is decreased. This increases the ability of CFRP composites to withstand cracks. However, the disadvantage was just a reduction in the distribution of laser energy, which contributes to a substantial reduction in the depth of the hole since it was modulated in the pulse mode (i.e. pulse ratio).

\section{ACKNOWLEDGEMENTS}

We express our heartfelt gratitude to Airbus in Broughton, United Kingdom for providing the material samples, and The Ministry of Higher Education, Malaysia (MOHE) together with Universiti Malaysia Kelantan (UMK) for the sponsorship of this research project (UMK-SIR-R/SIR/ A1300/01168A/002/2020/00765).

\section{REFERENCES}

Abdullah, I.H., Masri, M.N., Razali, M.H. \& Yusoff, M. 2019. Characterization of aluminum-titanium oxide-nickel oxide hybrid nanocomposite prepared by powder metallurgy. AIP Conference Proceedings 2068:1. https://aip.scitation.org/ doi/10.1063/1.5089351.

Abrate, S. \& Walton, D.A. 1992. Machining of composite materials - Part II: Non-traditional methods. Composites Manufacturing 3(2): 85-94.
Cenna, A.A. \& Matthew, P. 1997. Evaluation of cut quality of fibre-reinforced plastics-A review. Int. J. Mach. Tools Manufact. 37(6): 723-736.

Garrick, R. 2007. Drilling advanced aircraft structures with PCD (Poly- Crystalline Diamond) Drills. SAE Technical Paper 2007-01-3893.

Goeke, A. \& Emmelmann, C. 2010. Influence of laser cutting parameters on CFRP part quality. Physics Procedia 5: 253258.

Hernandez-Castaneda, J.C., Sezer, H.K. \& Li, L. 2011. The effect of moisture content in fibre laser cutting of pine wood. Optics and Lasers in Engineering 49: 1139-1152.

Kahar, S., Masri, M.N. \& Mohamed, M. 2017. The morphology and mechanical study on Neolamarckia cadamba and Endospermum diadenum in wood composite for particleboard application. Solid State Phenomena 264: 144-147. https://doi.org/10.4028/www.scientific.net/ ssp.264.144.

Kumar, S. 2014. Laser cutting process-A review. Int. J. of Darshan Institute on Engineering Research \& Emerging Technologies 3(1): 44-48.

Lau, W.S., Yue, T.M., Lee, T.C. \& Lee, W.B. 1995. Unconventional machining of composite materials. $J$. Materials Proc. Technol. 48: 199-205.

Li, Z.L., Zheng, H.Y., Lim, G.C., Chu, P.L., Li, L., Marimuthu, S., Negarestani, R., Sheikh, M. \& Mativenga, P. 2008. Process development of laser machining of carbon fibre reinforced plastic composites. International Congress on Applications of Lasers and Electro-Optics, ICALEO. Temecula, CA, USA.

Mangalgiri, P.D. 1999. Composite materials for aerospace applications. Bull. Mater. Sci. 22(3): 657-664.

Mathew, J., Goswami, G.L., Ramakrishnan, N. \& Naik, N.K. 1999. Parametric studies on pulsed Nd:YAG laser cutting of carbon fibre reinforced plastic composites. J. Materials Proc. Technol. 89-90: 198-203.

Rahim, E.A. \& Sasahara, H. 2018. High performance machining of carbon fiber-reinforced plastics, In Woodhead Publishing Series in Composites Science and Engineering, Sustainable Composites for Aerospace Applications, edited by Mohammad Jawaid \& Mohamed Thariq. Cambridge: Woodhead Publishing. pp. 211-226. ISBN 9780081021316. https://doi.org/10.1016/B978-0-08-102131-6.00010-4.

Reza, N. \& Li, L. 2013. Fibre laser cutting of carbon fibrereinforced polymeric composites. Proceedings of the Institution of Mechanical Engineers, Part B: Journal of Engineering Manufacture 0954405413490513.

Rusli, N.W., Abu Bakar, M.B., Ahmad Thirmizir, M.Z., Sulaiman, M.A. \& Masri, M.N. 2017. Flexural and morphology properties of kenaf fibre reinforcement unsaturated polymer composite. Materials Science Forum 888: 193-197. https://doi.org/10.4028/www.scientific.net/ msf.888.193. 
Sandvik Coromant. 2019. Machining Carbon Fibre Materials. http://www.sandvik.coromant.com/ sitecollectiondocuments/downloads/global/ technical\%20 guides/en-gb/c-2920-30.pdf. Accessed on 6th October 2019.

Shanmugam, D.K., Chen, F.L., Siores, E. \& Brandt, M. 2002. Comparative study of jetting machining technologies over laser machining technology for cutting composite materials. Composite Structures 57(1-4): 289-296.

Santhanakrishnan, G., Krishnamurthy, R. \& Malhotra, S.K. 1988. Machinability characteristics of fibre reinforced plastics composites. Journal of Mechanical Working Technology 17: 195-204.

Sheikh-Ahmad, J.Y. 2009. Machining of Polymer Composites. New York: Springer.

Singh, S.K. \& Maurya, A.K. 2017. Review on laser beam machining process parameter optimization. Int. J. for Innovative Research in Science \& Technology 3(8): 34-38.

Sobri, S.A., Heinemann, R., Whitehead, D. \& Shuaib, N.A. 2018a. Drilling strategy for thick carbon fiber reinforced polymer composites (CFRP): A preliminary assessment. Journal of Engineering and Technological Sciences 50(1): 21-39.

Sobri, S.A., Heinemann, R., Whitehead, D. \& Shuaib, N.A. 2018b. Preliminary investigation of drilling thick carbon fibre reinforced polymer composite (CFRP). AIP Conference Proceedings 2030, 020014. https://doi. org/10.1063/1.5066655.

Steen, W.M. \& Mazumder, J. 2010. Laser Material Processing. London: Springer-Verlag London Limited.

Sharizal Ahmad Sobri*, Mazlan Mohamed, Teo Pao Ter, Mohamad Najmi Masri \& Mohamad Bashree Abu Bakar

Advanced Material Research Cluster

Faculty of Bioengineering and Technology

Universiti Malaysia Kelantan Jeli Campus

17600 Jeli, Kelantan Darul Naim

Malaysia

Sharizal Ahmad Sobri*, Robert Heinemann \& David Whitehead Department of Mechanical, Aerospace and Civil Engineering The University of Manchester

Sackville Street Building, Sackville Street

Manchester M1 3WE

United Kingdom
Norshah Afizi Shuaib

Faculty of Mechanical Engineering Technology Universiti Malaysia Perlis, Pauh Putra Campus 02600 Arau, Perlis Indera Kayangan

Malaysia

Mohd Faisal Abdul Hamid

Department of Aerospace Engineering

Faculty of Engineering

Universiti Putra Malaysia

43400 UPM Serdang, Selangor Darul Ehsan

Malaysia

Wan Omar Ali Saifuddin Wan Ismail Faculty of Innovative Design and Technology Universiti Sultan Zainal Abidin, Gong Badak Campus 21300 Kuala Nerus, Terengganu Darul Iman Malaysia

Erween Abd Rahim

Faculty of Mechanical and Manufacturing Engineering Universiti Tun Hussein Onn Malaysia 86400 Parit Raja, Batu Pahat, Johor Darul Takzim Malaysia

Wan Ahmad Najmuddin Wan Saidin

Faculty of Engineering

DRB-HICOM University of Automotive Malaysia DRB-HICOM Automotive Complex

Lot 1449, PT 2204, Peramu Jaya Industrial Area 26607 Pekan, Pahang Darul Makmur Malaysia

Sharizal Ahmad Sobri* \& Norshah Afizi Shuaib Geopolymer and Green Technology

Centre of Excellence (CEGeoGTech)

Universiti Malaysia Perlis

01000 Kangar, Perlis Indera Kayangan Malaysia

*Corresponding author; email: sharizal.s@umk.edu.my

Received: 14 October 2020

Accepted: 18 January 2021 